CHAPTER 4

\title{
Greywater management in the northeastern Badia of Jordan
}

\author{
Wael Suleiman, Bassam Al-Hayek, Moayied Assayed, \\ Sahar Dalahmeh and Nisreen Al-Hmoud
}

\begin{abstract}
This chapter looks at the feasibility of adopting non-conventional GW management policies for small, rural communities in the north-eastern Badia of Jordan. The north-eastern Badia comprises 33 small clusters (communities), all of which lack public sewerage networks. The most common wastewater collection method is the use of pit latrines and unlined cesspools. About two-thirds of the population separate GW from blackwater, but use the GW for irrigation in an uncontrolled manner and without any treatment. A local stakeholder committee (LSC) formed of and including community members and officials was engaged in all project activities, including field visits to wastewater/GW treatment-and-use projects as well as a training workshop on public participation concepts and participatory rapid (or rural) appraisal (PRA) tools and methodologies. Relevant social, economic, and environmental data and information were collected utilizing PRA tools as well as formal surveys. One of the clusters - Rawdat Al-Amir Ali - was appointed as a research site based on specific criteria set by the research team and the LSC. Greywater quality and quantities generated from different fixtures of six households at the research site were investigated during the period March-August 2005. Different cost-effective and technologically-sound alternative treatment options were assessed, taking into consideration potential reuse opportunities. Two different treatment options were considered: 1) septic tank followed by intermittent sand filter; 2) up-flow anaerobic sludge blanket (UASB). Two pilot plants were designed, installed and operated in two households at the research site.
\end{abstract}

\section{Introduction}

The population of Jordan was estimated at 5.2 million in 2001, with an urban/rural balance of approximately 78 per cent/22 per cent. People in small, rural communities are located in about 1,145 clusters scattered all over the country (Table 4.1). These communities generally lack public sewerage services. Inhabitants rely mainly on inadequately managed on-site wastewater disposal systems that fail to protect the scarce water resources, public health and safety, and the surrounding environment because of the discretionary 
Table 4.1 Population distribution (2001)

\begin{tabular}{lll}
\hline Population range & No. of communities & Population \\
\hline$>50,000$ & 17 & $1,888,500$ \\
$10,000-50,000$ & 91 & $1,740,700$ \\
$5,000-10,000$ & 81 & 532,140 \\
$<5,000$ & $1,145^{*}$ & $1,020,660$ \\
\hline
\end{tabular}

* Considered small communities

Source: Department of Statistics, 2002

manner in which these systems have been designed, installed and managed (WHO, 2000).

The country is facing a future of very limited water resources, among the lowest in the world on a per-capita basis. Although access to safe drinkingwater supplies has been impressive, reaching over 96 per cent of the population, the expansion of modern sanitation systems to meet public health and environmental goals has lagged significantly behind, particularly in rural marginalized areas. This is mainly attributed to the present wastewater management policies that rely on centralized systems, hampering the extension of this service to small rural communities where inhabitants live in dwellings scattered over large areas. Interest in adopting non-conventional wastewater management strategies for small un-sewered communities in Jordan is rapidly increasing. However, this has not yet been investigated in an integrated framework (Al-Jayyousi, 2003).

The research investigated, in close consultation and with the active participation of the community, the feasibility of adopting innovative GW management policies for small rural communities in the country. This was approached through a coherent framework of activities, including the integration of various components of social, technical, economical, environmental and public participation requirements.

\section{Methodology}

The study area is the northeastern Badia that covers an area of about 25,600 $\mathrm{km}^{2}$, which is 28 per cent of the total area of the country, with a population of 25,820 in 2001 living in 33 clusters (Department of Statistics, 2002). The word Badia means the place where Bedouin people live. In the past, Bedouins were more nomadic than they are today. In recent times, their lifestyle has become more sedentary, requiring more infrastructure, facilities and services.

\section{Community participation}

Site visits to most of the communities in the study area were organized. Meetings were held with community leaders and representatives, municipality directors, principals of girls' and boys' schools and representatives of nongovernmental organizations (NGOs) and community-based organizations 
(CBOs) to introduce the study idea, objectives, methodology of work and the role of the community.

A local stakeholder committee (LSC) was formed by the communities in the area. The committee comprised 15 people, 4 women and 11 men, from different communities in the study area. The LSC was involved in different activities of the project. The researchers and the LSC met regularly and discussed various issues related to the project, including the technical aspects.

To build capacity among the public on different aspects of participatory development communication, the research team, in cooperation with external specialists, held a training workshop for four days at one of the CBO premises in the project area. The training focused on the concept of participation and participatory rapid (or rural) appraisal (PRA) tools and methodologies that could be used to identify wastewater problems and solutions based on the community's perspectives and needs. There was an emphasis on the more salient issues such as inhabitants' perceptions of water scarcity, GW use at the household level as an effective water demand management strategy and onsite wastewater management practices.

\section{Domestic visits to wastewater treatment and use projects}

Five field trips were organized for LSC and other community representatives in order to develop community-based 'know-how' and to share knowledge between the community and the research team that could help understand the issues and constraints faced in the setup and operation of wastewater treatment-and-use systems for small communities. The first visit was to the western part of the country, Deir Alla, where the Canadian International Development Agency (CIDA) funded a wastewater treatment-and-use project for an area comprising 13 communities with a total population of about 6,000 . The second trip was to the southern part of Jordan, Wadi Mousa, where a treatment-and-use project, funded by the United States Agency for International Development (USAID), has been operating since 2001 and serving three small communities. Two other field visits were organized to a university campus in the northern part of the country and to a nearby treatment-and-use project serving three small communities and a refugee camp. The fifth field visit was to small communities in the southern part of Jordan, Karak and Tafila cities, where the International Development Research Centre (IDRC), Canada, funded a GW treatment-and-use project for several communities in the area.

\section{Data collection}

Utilizing information obtained during the PRA training workshop, the researchers and LSC prepared a checklist to identify social, economic, environmental and technical issues related to the study based on the community's perspectives and needs. The checklist, shown in Table 4.2, was used as a tool to guide the team in collecting data during field visits to households. 


\section{GREYWATER USE IN THE MIDDLE EAST}

A work plan was prepared to cover the project area, with an aim to include 8-15 per cent of the population in data collection. Work teams were formulated; each consisted of 3-5 members, including at least one female member and a member of the research team. Each work team was assigned a study area with a minimum number of meetings to be conducted. A total of 404 meetings

Table 4.2 Checklist prepared and used by the local stakeholder committee

\begin{tabular}{|c|c|c|c|}
\hline & Suggested questions and topics & $\begin{array}{l}\text { Source } \\
\text { of data }\end{array}$ & $\begin{array}{l}\text { PRA tools to be } \\
\text { used }\end{array}$ \\
\hline Social issues & $\begin{array}{l}\text { Number of family members and their } \\
\text { educational levels } \\
\text { Number of wives } \\
\text { Income sources and rates } \\
\text { Frequency and cost of cesspool pump-outs }\end{array}$ & $\begin{array}{l}\text { Parents } \\
\text { Family } \\
\text { members }\end{array}$ & $\begin{array}{l}\text { Semi-structured } \\
\text { dialogue } \\
\text { Direct observations }\end{array}$ \\
\hline $\begin{array}{l}\text { Economic } \\
\text { issues }\end{array}$ & $\begin{array}{l}\text { Planted area around the residence and } \\
\text { water sources for irrigation } \\
\text { Number of owned livestock and drinking } \\
\text { water sources }\end{array}$ & Parents & $\begin{array}{l}\text { Semi-structured } \\
\text { dialogue } \\
\text { Direct observations }\end{array}$ \\
\hline $\begin{array}{l}\text { General } \\
\text { available } \\
\text { services }\end{array}$ & $\begin{array}{l}\text { Availability of different services (e.g. } \\
\text { charity societies, streets, schools, health- } \\
\text { care centres, drinking-water networks, } \\
\text { electricity, telephone networks, etc.) }\end{array}$ & $\begin{array}{l}\text { Individuals } \\
\text { Groups } \\
\text { Municipality } \\
\text { Charity } \\
\text { association }\end{array}$ & $\begin{array}{l}\text { Semi-structured } \\
\text { dialogue } \\
\text { Direct observations }\end{array}$ \\
\hline $\begin{array}{l}\text { Environmental } \\
\text { issues }\end{array}$ & $\begin{array}{l}\text { Current wastewater disposal practices and } \\
\text { adverse impacts on public health and the } \\
\text { environment (potential groundwater } \\
\text { pollution) } \\
\text { How do you perceive the impacts of using } \\
\text { treated wastewater for irrigation? } \\
\text { Do you separate wastewater coming out of } \\
\text { the kitchen and the bathroom (GW) from } \\
\text { that of the toilet? If yes, why and how do } \\
\text { you get rid of it? } \\
\text { Are there any GW use practices? Are these } \\
\text { planned or not? } \\
\text { Do you accept reusing treated wastewater } \\
\text { for irrigation?Do you prefer to treat and use } \\
\text { GW or wastewater as a whole? What is the } \\
\text { frequency of cesspool pump-outs? How } \\
\text { much does this cost you? } \\
\text { What is the distance between your } \\
\text { residence and the dumping site? } \\
\text { What wastewater management alternatives } \\
\text { do you suggest? }\end{array}$ & $\begin{array}{l}\text { Individuals } \\
\text { Family } \\
\text { members } \\
\text { Groups } \\
\text { Municipality } \\
\text { Charity } \\
\text { associations }\end{array}$ & $\begin{array}{l}\text { Semi-structured } \\
\text { dialogue } \\
\text { Ranking, } \\
\text { Problem and } \\
\text { solution network } \\
\text { Mapping } \\
\text { Direct observations } \\
\text { Seasonal calendar } \\
\text { Historical } \\
\text { background } \\
\text { Daily routine }\end{array}$ \\
\hline Water issues & $\begin{array}{l}\text { Is the municipal water supply adequate? } \\
\text { Any other alternatives? } \\
\text { How much does municipal water cost you? } \\
\text { What are the differences in water } \\
\text { consumption between summer and winter? }\end{array}$ & $\begin{array}{l}\text { Family } \\
\text { members } \\
\text { Groups } \\
\text { Municipality } \\
\text { Charity } \\
\text { associations }\end{array}$ & $\begin{array}{l}\text { Semi-structured } \\
\text { dialogue } \\
\text { Direct observations } \\
\text { Seasonal calendar } \\
\text { Historical } \\
\text { background } \\
\text { Daily routine }\end{array}$ \\
\hline
\end{tabular}


were carried out during 13 days of field work. In addition, a formal survey was conducted to collect relevant data and information utilizing questionnaires.

\section{Identification of an appropriate community}

The authors set criteria to identify one community within the project area as the research site where pilot field-experiments for GW collection, treatment and use were to be conducted. These criteria included:

- the opportunity to improve current wastewater management practices;

- social acceptance and favourability for use;

- representation and potential for replication;

- institutional support and the presence of NGOs and/or CBOs.

Together with the LSC, the researchers reviewed the data and information collected to screen the communities. A considerable number of communities were excluded due to the fact that favourability for use was limited either due to the type of soil or because of the limited agricultural activities. Other sites were excluded because of the limited potential for replication in areas that do not adequately represent the project area (in terms of population and income rate). Some communities were also rejected due to the lack of NGOs and/or CBOs that could provide appropriate institutional support.

The group selected a list of seven communities. Site visits were conducted to these communities and further screening was carried out. Finally, the group decided to identify Rawdat Al-Amir Ali as the research-project site.

\section{Greywater quality and quantity}

There are three modes used to collect GW generated from households at the research site. These are: collecting all the generated GW at one discharge point; collecting water coming out of the kitchen in one point, and other GW sources in another point; and collecting water coming out of the kitchen, water coming out of ablution and hand washing and other GW sources in separate discharge points.

Quality and quantities of GW discharged at the different points were investigated during the period March-August 2005. A total of six households, each following the same trend of GW separation, were selected in cooperation with the LSC for this purpose. Generated quantities were measured on a daily basis, while composite samples were collected bimonthly from each discharge point. Samples were carefully placed in containers and kept in an ice-box at a temperature of less than $4^{\circ} \mathrm{C}$. All analytical tests were performed in accordance with the Standard Methods for The Examination of Water and Wastewater (APHA et al., 1998). 


\section{Selection of the appropriate treatment system}

A literature survey was conducted that included studying many of the lowcost technologically-sound treatment alternatives that are/were used on a small scale as on-site or decentralized treatment systems, taking into consideration potentials of reusing reclaimed water. In order to evaluate each of the treatment options mentioned above, certain selection criteria were set taking into consideration GW quality and quantity, community requirements, and local regulations. In addition, an expert group consisting of the research team, local wastewater treatment-and-use experts and a representative of the LSC was formulated to establish a network for discussion, information exchange, assessment, and evaluation of affordable and attractive options for GW treatment that are suitable for the local environment/social conditions.

\section{Results}

\section{Social, economic and environmental information}

The total population of the study area was estimated at 28,480 in 2004, distributed in 33 small clusters. The society is characterized as a youthful one with more than 40 per cent of the population under the age of 15. About 18.5 per cent of the population is illiterate, and the average number of family members is nine. The average monthly income rate is estimated at JOD123 per family (base on exchange rates of May 2009, JOD1 = US\$1.41).

The study area suffers from a water shortage problem. Domestic water is being supplied through the public network for only 24 hours a week and inhabitants purchase water from the private sector particularly in the summer period. People spend around 5 per cent of their income on their water bill. Agricultural activities in the area are limited and only possible through irrigation. Wheat and barley are the main crops grown. The main obstacle facing agriculture in the area is water scarcity.

The community relies mainly on unlined cesspools as an on-site wastewater collection system. Cesspools at some clusters are rarely emptied, and at other clusters are pumped out on a monthly basis, with an average entailed cost of JOD21. The closest legal liquid-waste dumping site is $80 \mathrm{~km}$ away from the area and inhabitants believe that wastewater pumped out of cesspools is being illegally disposed of in nearby streams. About 62 per cent of the public in the study area utilize pit latrines or ventilated improved pit latrines, 33 per cent have traditional (no-flush) indoor toilets, and only 1 per cent use a flush toilet (compared to 89 per cent on the national level). Only 40 per cent of the community have showers and kitchen sinks.

As for GW, two-thirds of the community indigenously separate GW from blackwater, mainly for religious reasons. Greywater is being used directly and without any treatment for irrigating planted areas in the backyards in an uncontrolled manner, paying no formal attention to health aspects. 


\section{Greywater quality and generation rates}

During the period March-August 2005, GW quantities generated at the six dwellings involved in the study were measured on a daily basis. Some relevant information was also collected, such as number of family members, number of children per family, type of toilet used and the availability of showers and/or bathing tubs. In addition, composite samples over a 24-hour period were collected bimonthly and analysed for physical, chemical and microbial constituents.

Greywater generation rates ranged from 12.0-19.0 litres/capita/day (1/c/d). Quantities generated from the kitchen comprised about 50 per cent of the total GW quantity generated from all the discharge points, while the quantities generated from ablution and hand washing were the lowest. The highest generation rate was for a household that had an indoor toilet. Lower generation rates were observed for households that did not have showers or basins for bathing.

The results from the survey conducted on GW quality are shown in Table 4.3. They indicate that the quality varied highly among the common collection points (same sources of GW) in different households. This was mainly attributed to the different activities that were undertaken during sampling (e.g. washing clothes, washing floors and others). The fat, oil and grease (FOG) content was found to be higher than that in wastewater generated in other communities, particularly urban ones. This could be attributed to the food style and meal patterns. The organic content was higher for GW coming out of the kitchen than other GW sources. The levels were higher for households with higher numbers of children. One of the practices in such communities is that mothers do not use nappies for children, and it is common practice to clean children in basins that led to GW discharge points. It was also quite common for inhabitants to wash their hands in the ablution basins or kitchen sinks after going to pit latrines or toilets. Escherichia coli (E. coli) levels were also higher than expected even for GW coming out of the kitchen sinks and ablution basins.

Levels of macro-nutrients (nitrogen T-N, phosphorous T-P, and potassium K) were lower for water generated from the kitchen sinks and ablution basins compared to levels for water generated from other sources. The $\mathrm{pH}$ levels of GW collected from the kitchen sinks were lower than those of water generated from other sources. This was found to be in agreement with results obtained by other researchers (Burnat, 1997; Dixon et al., 1999a, b).

Comparing the microbial quality of GW with the World Health Organization (WHO) guidelines of 1989 for the use of wastewater in irrigation, it is likely that GW quality at all discharge points is suitable only for restricted irrigation, i.e. of cereal crops, industrial and fodder crops, pasture and trees. According to the WHO guidelines, it is not recommended to use such water to irrigate crops likely to be eaten uncooked, sports fields and public parks. The guidelines also impose site restrictions and recommend people not to 
66 GREYWATER USE IN THE MIDDLE EAST

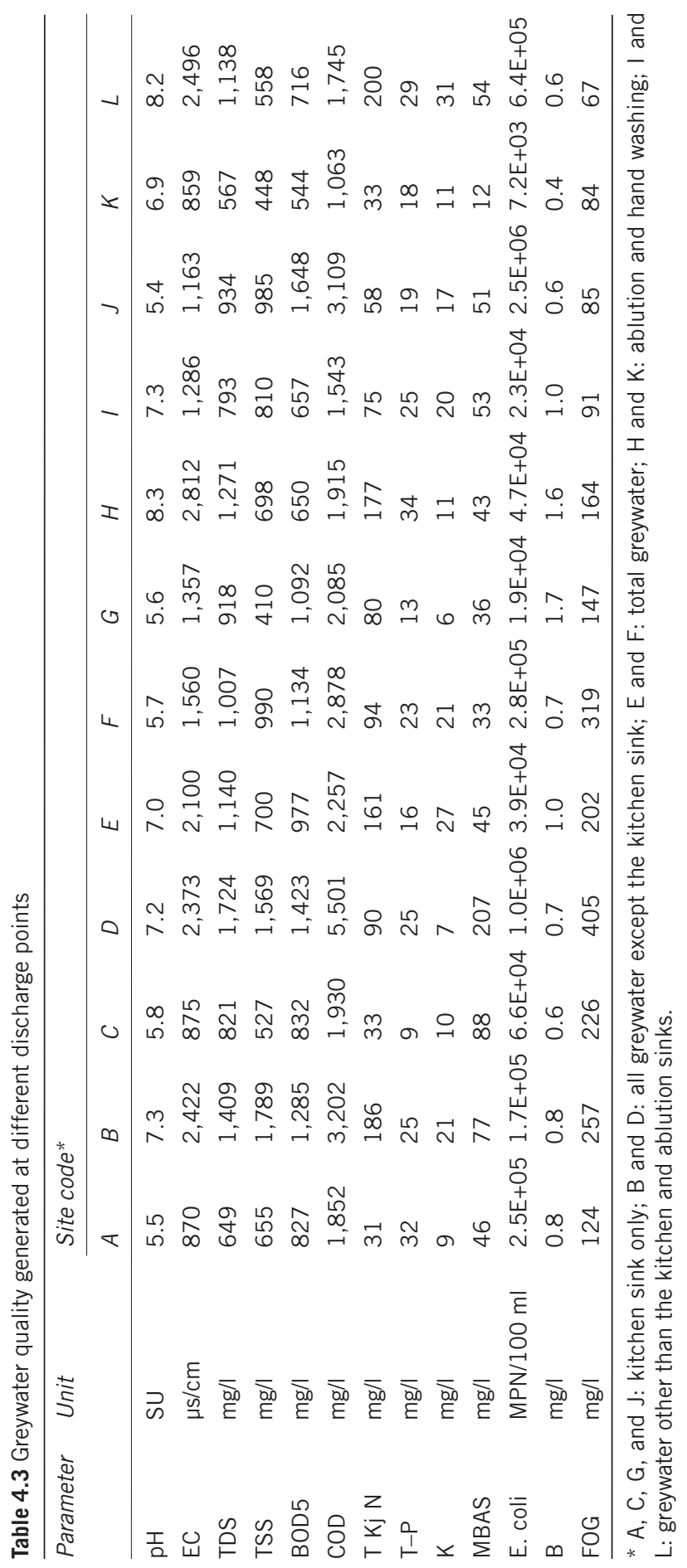


be exposed to such water unless they wear gloves and have safety shoes. The project team illustrated this to the LSC members during one of the meetings. It is worth mentioning that unrestricted irrigation, according to the aforementioned WHO guidelines, applies only for water with less than 1,000 MPN/100 $\mathrm{ml}$ of total thermo-tolerant coliform count TTCC (or E. coli) and of $\leq 1.0$ egg of intestinal pathogenic nematodes/l.

\section{Treatment options and pilot experiments}

The following design criteria were adopted for identifying appropriate treatment options:

- $\mathrm{BOD}_{5}=1,000 \mathrm{mg} / \mathrm{l}$;

- $\mathrm{TSS}=750 \mathrm{mg} / \mathrm{l}$;

- $\mathrm{GW}$ generation rate $=200$ litres/family/day;

- reclaimed water is to be used for restricted irrigation.

The study team, including the local expert group, developed an evaluation matrix to assess different treatment alternatives as shown in Tables 4.4 and 4.5. The team was in favour of utilizing one or more of the following treatment options, taking into account the socioeconomic characteristics of the study area an up-flow anaerobic sludge blanket (UASB) or septic tank followed by intermittent sand filter.

Two pilot plants were designed, constructed, and operated during the period March-August 2006. Design drawings for sand filter and UASB units are shown in Figures 4.1 and 4.2, respectively. The performance of each plant in treating generated GW was evaluated and the results are shown in Table 4.6. The septic tank/sand filter system gave a high performance in removing organic and solid contents. BOD $_{5}$ and TSS reductions of 86 per cent and 81 per cent were demonstrated, with effluent concentrations of $67 \mathrm{mg} / \mathrm{l}$ and 37 $\mathrm{mg} / \mathrm{l}$ respectively. In addition, $E$. coli counts were drastically reduced by four logs to levels below 1,000 MPN/100 ml. The UASB system indicated high performance as well with $\mathrm{BOD}_{5}$ and TSS reductions of 79 per cent and 87 per cent for effluent concentrations of $223 \mathrm{mg} / \mathrm{l}$ and $80 \mathrm{mg} / \mathrm{l}$, respectively. However, this system showed a lower $E$. coli reduction compared to the septic tank/sand filter system.

The performance of UASB in removing pathogens improved upon the provision of the unit with a small filter of zeolite. The zeolite filter not only improved the pathogenic removal, but it also markedly improved the removal of organic matter and suspended solids, detergent, oil, and grease (the overall efficiency is shown in Table 4.7).

According to the WHO guidelines for the use of reclaimed water mentioned earlier, effluent coming from the intermittent sand filter is suitable for unrestricted irrigation. However, the community was oriented to use reclaimed GW for restricted irrigation only. This is mainly due to the fact that Jordanian regulations do not allow the use of reclaimed water for unrestricted irrigation 
68 GREYWATER USE IN THE MIDDLE EAST

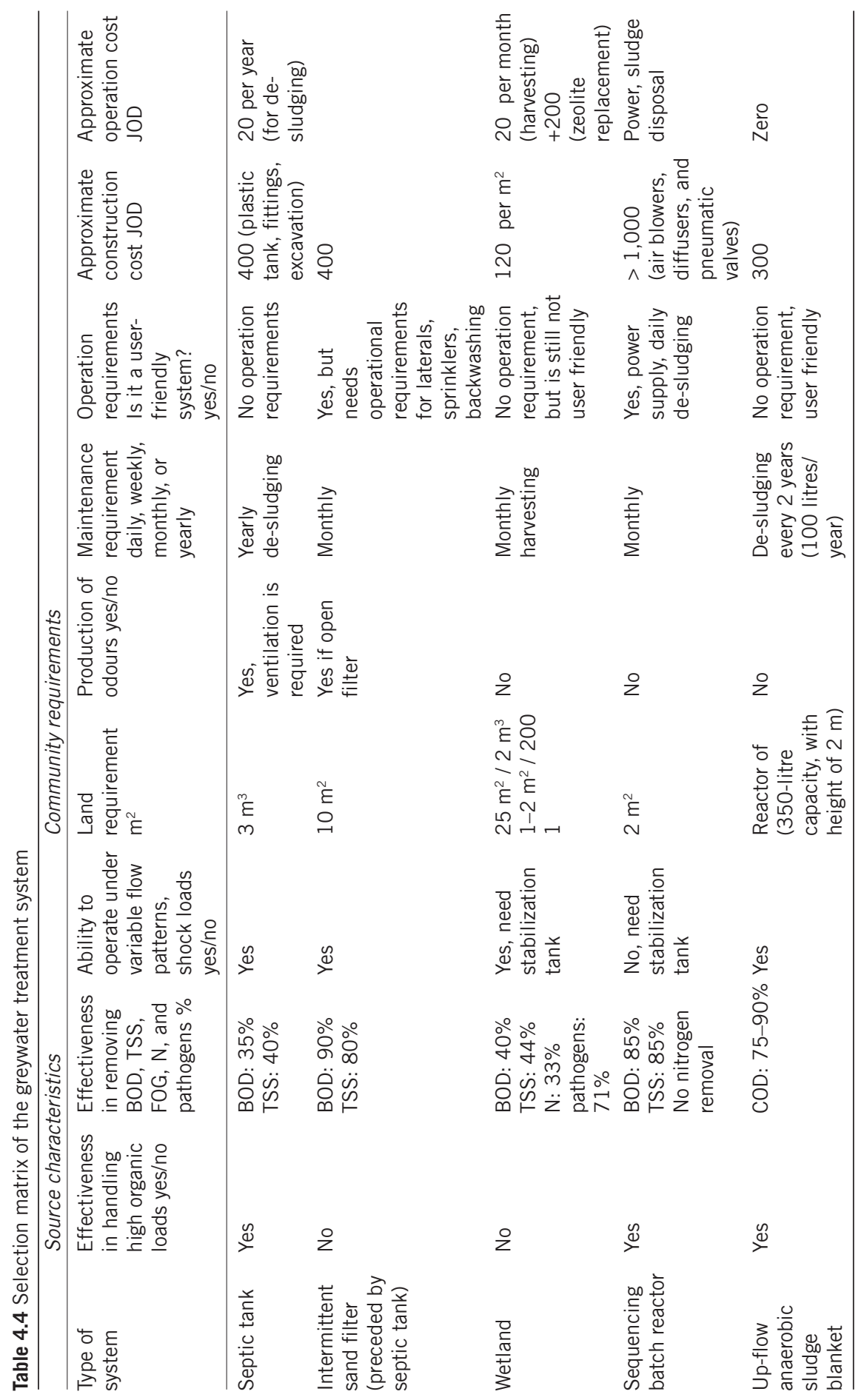




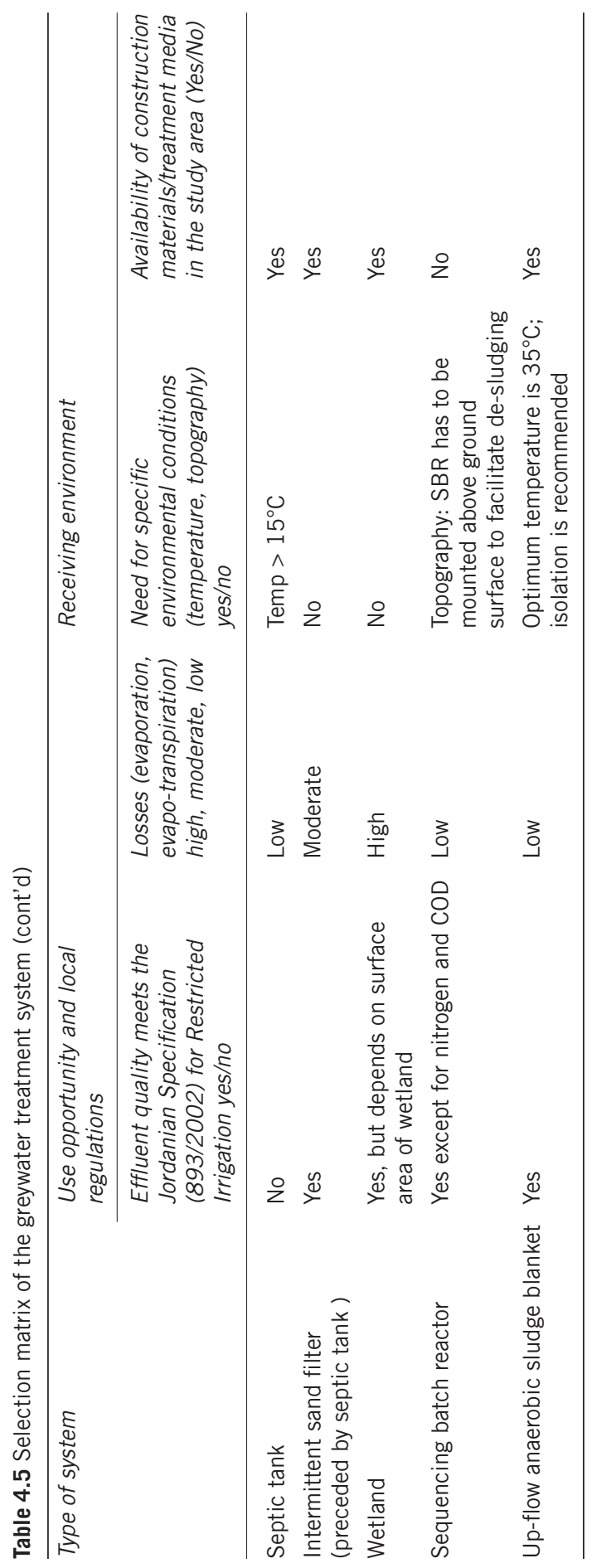




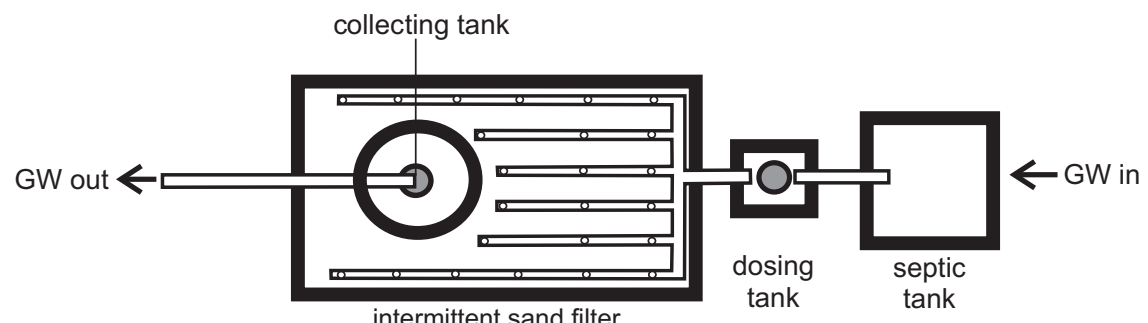

intermittent sand filter

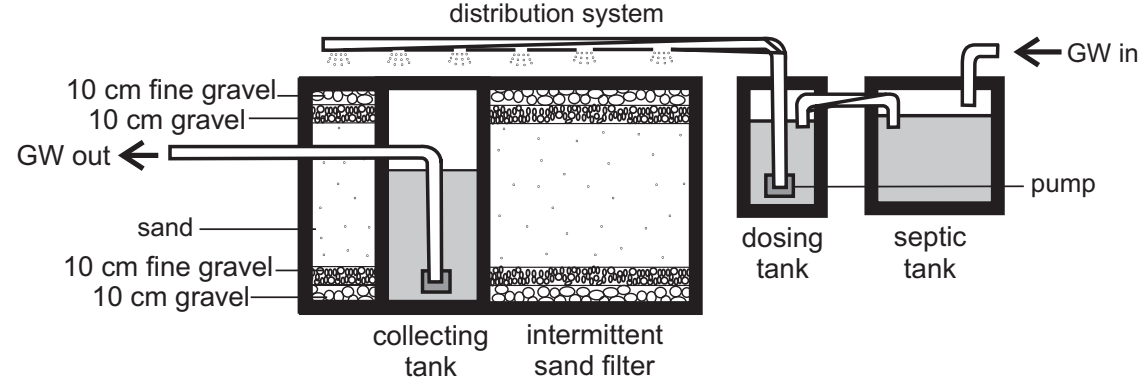

Figure 4.1 Septic tank-sand filter unit

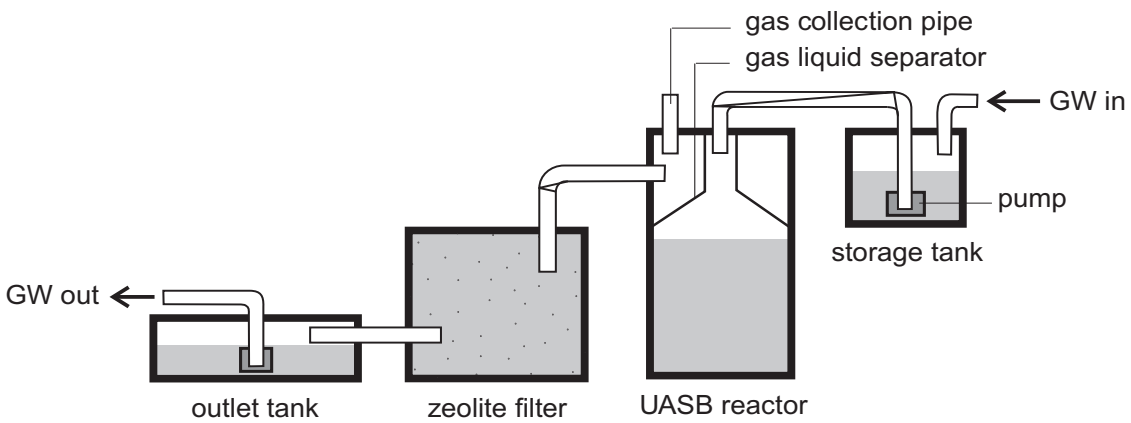

Figure 4.2 Up-flow anaerobic sludge blanket sludge (UASB) reactor

regardless of its quality, and also to minimize potential health risks that could arise due to improper operational manners.

A training seminar on the construction, operation, and maintenance of GWT units was organized. The seminar targeted community members (men and women) and aimed at building up the knowledge and hands-on expertise of the sand filters and UASB treatment units. 
Table 4.6 Performance of septic tank/sand filter system

\begin{tabular}{|c|c|c|c|c|c|c|}
\hline \multirow[t]{2}{*}{ Parameter } & \multirow[t]{2}{*}{ Unit } & \multirow[b]{2}{*}{$\begin{array}{l}\text { JS(893/2006) Use } \\
\text { for fodder and } \\
\text { industrial crops and } \\
\text { cooked vegetables } \\
\text { (maximum } \\
\text { allowable limit) }\end{array}$} & \multicolumn{4}{|c|}{ Septic tank/intermittent sand filter } \\
\hline & & & $\begin{array}{l}\text { Raw } \\
\text { greywater }\end{array}$ & $\begin{array}{l}\text { Effluent } \\
\text { from } \\
\text { septictank }\end{array}$ & $\begin{array}{l}\text { Effluent } \\
\text { from } \\
\text { sandfilter }\end{array}$ & $\begin{array}{l}\text { Overall } \\
\text { efficiency } \\
\%\end{array}$ \\
\hline BOD5 & $\mathrm{mg} / \mathrm{l}$ & 300 & 1,182 & 438 & 59 & 95 \\
\hline COD & $\mathrm{mg} / \mathrm{l}$ & 500 & 2,248 & 951 & 161 & 93 \\
\hline TSS & $\mathrm{mg} / \mathrm{l}$ & 300 & 609 & 206 & 31 & 95 \\
\hline FOG & $\mathrm{mg} / \mathrm{l}$ & 8 & 159 & 17 & 8 & 95 \\
\hline MBAS & $\mathrm{mg} / \mathrm{l}$ & 100 & 27 & 39 & 12 & 53 \\
\hline NO3-N & $\mathrm{mg} / \mathrm{l}$ & 10 & 47 & 2 & 1 & 98 \\
\hline NH3-N & $\mathrm{mg} / \mathrm{l}$ & - & 53 & 100 & 50 & 5 \\
\hline T Kj N & $\mathrm{mg} / \mathrm{l}$ & - & 112 & 108 & 50 & 56 \\
\hline T-N & $\mathrm{mg} / \mathrm{l}$ & 70 & 211 & 210 & 101 & 52 \\
\hline T-P & $\mathrm{mg} / \mathrm{l}$ & 30 & 20 & 19 & 8 & 57 \\
\hline SAR & Unitless & 9 & 7 & 6 & 4 & 40 \\
\hline E. coli & MPN/100 ml & - & $2.17 \mathrm{E}+03$ & $5.86 \mathrm{E}+05$ & $2.27 \mathrm{E}+02$ & 90 \\
\hline
\end{tabular}

- no limits in the standard

Table 4.7 Performance of UASB/zeolite system

\begin{tabular}{|c|c|c|c|c|c|c|c|c|}
\hline \multirow{2}{*}{$\begin{array}{l}\text { Para- } \\
\text { meter }\end{array}$} & \multirow[t]{2}{*}{ Unit } & \multirow[b]{2}{*}{$\begin{array}{l}S \\
\text { (893/2006) } \\
\text { Use for } \\
\text { fodder and } \\
\text { industrial } \\
\text { crops and } \\
\text { cooked } \\
\text { vegetables } \\
\text { (maximum } \\
\text { allowable } \\
\text { limits) }\end{array}$} & \multicolumn{6}{|c|}{ UASB/zeolite filter } \\
\hline & & & $\begin{array}{l}\text { Effluent } \\
\text { from } \\
\text { storage } \\
\text { tank }\end{array}$ & $\begin{array}{l}\text { Effluent } \\
\text { from } \\
\text { UASB }\end{array}$ & $\begin{array}{l}\text { Effluent } \\
\text { from } \\
\text { zeolite } \\
\text { filter }\end{array}$ & $\begin{array}{l}\text { Efficiency } \\
\text { of UASB } \\
\%\end{array}$ & $\begin{array}{l}\text { Efficiency } \\
\text { of } \\
\text { zeolite } \\
\text { filter } \%\end{array}$ & $\begin{array}{l}\text { Overall } \\
\text { efficiency } \\
\%\end{array}$ \\
\hline BOD5 & $\mathrm{mg} / \mathrm{l}$ & 300 & 1,051 & 291 & 223 & 72 & 23 & 79 \\
\hline COD & $\mathrm{mg} / \mathrm{l}$ & 500 & 2,030 & 761 & 429 & 63 & 44 & 79 \\
\hline TSS & $\mathrm{mg} / \mathrm{l}$ & 300 & 596 & 137 & 80 & 77 & 42 & 87 \\
\hline FOG & $\mathrm{mg} / \mathrm{l}$ & 8 & 136 & 76 & 8 & 44 & 89 & 94 \\
\hline MBAS & $\mathrm{mg} / \mathrm{l}$ & 100 & 37 & 14 & 11 & 63 & 18 & 70 \\
\hline NO3-N & $\mathrm{mg} / \mathrm{l}$ & 10 & 3 & 0 & 1 & 99 & ** & 63 \\
\hline NH3-N & $\mathrm{mg} / \mathrm{l}$ & - & 5 & 5 & 4 & 2 & 19 & 20 \\
\hline $\mathrm{T} \mathrm{Kj} \mathrm{N}$ & $\mathrm{mg} / \mathrm{l}$ & - & 36 & 13 & 15 & 63 & ** & 58 \\
\hline $\mathrm{T}-\mathrm{N}$ & $\mathrm{mg} / \mathrm{l}$ & 70 & 44 & 18 & 20 & 58 & ** & 54 \\
\hline T-P & $\mathrm{mg} / \mathrm{l}$ & 30 & 12 & 4 & 2 & 65 & 42 & 80 \\
\hline SAR & Unitless & & 5 & 9 & 2 & ** & 82 & 65 \\
\hline \multirow[t]{2}{*}{ E. coli } & \multicolumn{8}{|l|}{ MPN/ } \\
\hline & $100 \mathrm{ml}$ & - & $1.74 \mathrm{E}+06$ & $5.17 \mathrm{E}+06$ & $2.22 \mathrm{E}+05$ & ** & 96 & 87 \\
\hline
\end{tabular}

** no removal of pollutant occurred

- no limits in the standard 


\section{Cost-benefit analysis of the two selected treatment units}

The use of treated GW benefited the targeted households in reducing the domestic water consumption rates, thus saving the household some money for other purposes. On the other hand, the availability of such an alternative resource increased the farming productivity particularly in terms of olives and olive oil. A simple cost-benefit analysis of the two scenarios of treatment is shown in Tables 4.8 and 4.9 .

From economic and water-saving points of view and based on the costbenefit analysis, it was found that a treatment unit that serves a group of houses is more feasible than one that serves a single house, as the costs will be shared among the group and the generated water quantities will be higher. Moreover, the savings on water bills will be more substantial for a group of houses than for a single house.

\section{Conclusion}

Participatory approaches, taking into account the knowledge and experience of local people, need to be applied when investigating integrated water-resources management programmes for small communities. In this respect, intensive awareness campaigns are essential to inform the communities of current issues and new trends in water-resource management. Field visits of local people to wastewater treatment-and-use projects are important to develop community-

Table 4.8 Cost-benefit analysis of UASB treatment unit

\begin{tabular}{lll}
\hline Scenarios & Costs and benefits & UASB unit cluster of 4 houses \\
\hline Saving on water bill & Cost of unit (JOD) & 613 \\
+ & Water saving (m3/ year) & 144 \\
Production of olive oil & Saving on water Bill (JOD/year) & 49.6 \\
& Olive oil production (no. of tank/year) & 5 \\
& Cost of olive oil (JOD/year) & 250 \\
\hline & Total benefit (JOD/year) & 299.6 \\
& Payback period (year) & 2.04 \\
\hline
\end{tabular}

Table 4.9 Cost-benefit analysis of septic tank/sand filter treatment unit

\begin{tabular}{lll}
\hline Scenarios & Costs and benefits & Sand filter unit \\
\hline Saving of Water Tankers costs & Cost of unit (JOD) & 834 \\
& Water saving (m3/ year) & 54 \\
Production of Olive Oil & Cost of water tankers (JOD/year) & 121.5 \\
& Olive oil production (no. of tank/year) & 1 \\
& Cost of olive oil (JOD/year) & 50 \\
\hline & Total benefit (JOD/year) & 171.5 \\
& Payback period (year) & 4.86 \\
\hline
\end{tabular}


based know-how and to share knowledge and ideas. All of these actions form a new base of knowledge and sound management experience, tailored to the needs and situation of the communities in consideration.

Greywater is a vital and sustainable water resource that should receive considerable attention when targeting wastewater management in small communities. Greywater treatment and use for irrigation could be an effective water-demand management strategy for small clusters in Jordan. However, the practices and habits of the community highly affect both GW generation rates and GW quality, particularly in terms of microbial and organic contents. Current practices of GW use need to be improved, taking into consideration health aspects.

Based on the treatment technology selection matrix, which was developed by the project team and the expert committee with participation of LSC representatives, it was found that two treatment technologies can be used to treat GW generated in small rural communities in the Badia of Jordan. These are: 1) septic tank followed by intermittent sand filter (ISF); 2) septic tank followed by an up-flow anaerobic sludge blanket (UASB). The septic tank followed by intermittent sand filter showed high performance in treating GW in terms of physical, chemical, and microbial aspects. The sand filter was very effective in removing the pathogens indicated by E. coli. The performance of the UASB system in removing pathogens was improved after providing the system with a post treatment zeolite filter. Although both systems were efficient in treating fairly contaminated GW, the UASB coupled with a zeolite filter was easier to operate and maintain, and was more cost effective.

Reclaimed water from the systems investigated could be used for restricted irrigation. On a family level, it can be said that GW use can contribute somehow to improving food security (olive fruit and olive oil) and enhance the household income.

\section{Acknowledgements}

This research study was conducted by the Environmental Research Center of the Royal Scientific Society, under a grant from the International Development Research Centre (IDRC), Canada. The authors appreciate the support of Dr. Lamia El Fattal, senior program officer at IDRC. Grateful acknowledgement is made to Eng. Othman Mashaqbeh and the environmental and socioeconomic team of the Royal Scientific Society who participated in the research activities.

The team also acknowledges the cooperation of CARE International in Jordan/CARE Australia and PLAN:NET, Canada, for designing and implementing a training workshop for four days at one of the CBOs in the project area.

Grateful appreciation also is extended to all members of the communities and public organizations who participated and contributed to the success of this research study. 


\section{References}

Al-Jayyousi, O.R. (2003) 'Greywater reuse: Towards sustainable water management', Desalination 156: 181-92.

American Public Health Association (APHA), American Water Works Association (AWWA) and Water Environment Federation (WEF) (1998) Standard Methods for the Examination of Water and Wastewater, 20th edn, APHA, Washington D.C.

Burnat, J. (1997) 'On-site wastewater treatment, disposal and re-use: Treatment strategies for the unsewered areas in the West Bank', IHE, Delft, the Netherlands.

Department of Statistics (2002) Statistical Yearbook, Jordan.

Dixon, A., Butler, D. and Fewkes, A. (1999a) 'Guidelines for greywater re-use: Health issues', Journal of the Chartered Institution of Water and Environmental Management (CIWEM) 13: 322-26.

World Health Organization (WHO) (1989) Health Guidelines for the Use of Wastewater in Agriculture and Aquaculture (Technical Report Series 778), WHO, Geneva.

WHO (2000) Proceedings of the Technical Expert Consultation on Appropriate and Innovative Wastewater Management for Small Communities in EMR Countries, Eastern Mediterranean Regional Office, Regional Center for Environmental Health Activities, Jordan.

\section{About the authors}

Wael Suleiman is a researcher at the Environmental Research Center of the Royal Scientific Society, with focus on wastewater management, treatment, and reuse, bio-solids management and water quality monitoring and assessment. He is a principal researcher in Integrated Wastewater Management Policies and Technologies for Marginal Communities in Jordan, an IDRC-funded project. He is also the project leader in Integrated Graywater Management Policies for Large Water Consumers in Vulnerable Communities of Jordan, an applied research project funded by WADIMENA/IDRC. He holds an MSc in Civil Engineering from the University of Jordan with focus on water and environmental issues. Email: wael@rss.gov.jo

Bassam Al-Hayek is the Director of the Environmental Research Center (ERC) at the Royal Scientific Society.

Moayied Assayed is a researcher at the Environment Research Center of the Royal Scientific Society, and has professional experience in greywater management, risk assessment and water demand management.

Sahar Dalahmeh is Sahar Dalahmeh is an engineer at the Royal Scientific Society.

Nisreen Al-Hmoud is head of water quality studies division at the Energy Research Center. 
PART II

Socioeconomic aspects 
This page intentionally left blank 